\title{
Is Engineering Education Delivering What Industry Requires?
}

\author{
Elizabeth May \\ Master's Candidate in Mechanical \\ Engineering, \\ Faculty of Applied Science, \\ Queen's University, Kingston, Ontario \\ may@me.queensu.ca
}

\author{
David S. Strong \\ Professor and NSERC Chair in Design \\ Engineering, \\ Faculty of Applied Science, \\ Queen's University, Kingston, Ontario \\ strongd@ilc.queensu.ca
}

\begin{abstract}
Engineering graduates from the current Canadian university system leave school expecting to be wellequipped for engineering practice. After years of intense study, these bright and eager engineering graduates plan to design cars, construct bridges, and develop computer systems. However, for some time, surveys have suggested that employers find engineering graduates to be weak in the field of engineering design, innovation, communication, and associated professional skills. It is not likely that this is the fault of the student, but one may question whether design and professional skills requirements in engineering curricula are adequate [1]. Industry feedback suggests that changes are required in Canadian engineering education.
\end{abstract}

\section{Introduction}

For some time, engineering education literature has suggested that the capability of engineering graduates does not meet the expectations of industry employers. For our engineering graduates to compete successfully in a globally competitive employment market, it is critical that this gap in knowledge and skills be clearly understood in order for engineering education to respond accordingly. To meet this need, a new survey of practicing engineers has been conducted. In parallel, graduating students nationwide have responded via entry and exit surveys for their capstone design courses to clearly determine what skills and knowledge are being developed - or not - in these courses. Ultimately, it is our intention to integrate this information to "design" engineering education that meets the needs of all stakeholders.

\section{What is Engineering Design?}

Design, as defined by the former President of the Natural Sciences and Engineering Research Council of Canada (NSERC), Tom Brzustowski [2], is the "central creative process" of engineering. As difficult as it may be to define, design is, in fact, the essence of engineering. The
Canadian Academy of Engineering [3] states that, "Engineering is a profession concerned with the creation of new and improved systems, processes, and products to serve human needs. The central focus of engineering is design, an art entailing the exercise of ingenuity, imagination, knowledge, skill, discipline, and judgment based on experience. The practice of professional engineering requires sensitivity to the physical potential of materials, to the logic of mathematics, to the constraints of human resources, physical resources and economics, to the minimization of risk, to the protection of the public and the environment." The engineering design process involves a rigorous set of steps to create or enhance a product, process, or system.

Engineers aren't faced only with the required ingenuity and technical challenges of design, but must also contend with the needs, expectations, and influences of society. It is possible for an engineer to design a product, process, or system that will greatly benefit human kind, but unless human kind can accept this new design as being useful, the effort has been pointless. Throughout his text, Pool [4] brings to light many interesting conundrums dealing with society and technology. Ultimately, he demonstrates that, in order to survive, a technology must be approved and accepted by the society within which it is 
integrated. Society often finds it difficult to readily accept new technology; it is hard to commit to something one knows nothing - or very little - about. Rather than readily accepting new technology, society frequently wants nothing to do with it. Fear, it seems, holds a great deal of power when it comes to society's grips on technology. When introducing new designs or technologies, engineers must consider the impact it will have on society - and the impact that society will have on the success of the design. If the engineer doesn't consider the wants and needs of a user, he has missed the most crucial steps in the engineering design process.

A design, to be successful, requires insight from more than one point of view. For best results, the ideal design is conceived when a diverse group of people are brought together to discuss their innovative ideas. With a variety of perspectives, it is easier to develop a design that meets the standards of a wider range of people. With a diverse group, the opportunity to brainstorm and build on fellow teammates' ideas flourishes. Similarly, the past experiences with disaster, near disaster, and success bring a broad vision to a given objective. For example, Chiles [5] discusses the issue of "tunnel vision" in a design. When "people [are] so devoted to a goal, so feverish in their daily activity, so narrow in their vision that lessons from mishaps and near misses outside their own program [make] little impression" failure is inevitable. When engineering teams are composed of broad based backgrounds, it is more likely that the individual opinions and ideas can be brought together to eliminate disaster. The ability to work as a team is typically imperative to the success of a design.

\section{History of Engineering Design Education and the Resistance to Change}

Industry and engineering practice have undergone significant evolution in the past few decades; it therefore seems appropriate that engineering education must do the same in order to maintain an effective pace. The evolution of engineering education, however, comes as a significant challenge. Regardless of how significant the changes to engineering practice have been, engineering education tends to respond very slowly. The current North American model of engineering education stems directly from the Grinter Report [6] - a significant step in the evolution of engineering education, published in 1955.

A publication of the American Society of Engineering Education (ASEE) Committee on Evaluation of Engineering Education, the Grinter Report strongly advocated change in engineering curriculum. As a result of scientific advances at that time, such as radar and operations research during WWII, the document stressed the necessity for a strong science-based curriculum in engineering schools. When the Soviet Union launched Sputnik in 1957, effectively beating the United States into space, the proposals outlined in the document appeared to be unarguable.

As with most recommendations for engineering education, the ASEE committee, chaired by L.E. Grinter, proposed that, in addition to a focus on science oriented curriculum, engineering education must develop students capable of facing new engineering situations with competence, in respect to professional and social responsibilities. In order to meet this target, however, academe reacted by only stressing that a scientificallyoriented engineering curriculum be essential. It was deemed crucial that emphasis in the basic sciences, mathematics, chemistry, and physics be strengthened. In addition, six engineering sciences were suggested as core to the engineering curricula.

The fundamental content and pedagogy in engineering education appear to have evolved minimally in the past fifty years. In the Grinter report [6], it was stated that "we do not seem to have produced an equivalent counterpart in the reorganization of engineering curricula" to meet the great changes in engineering practice. Five decades after this report was published, how many engineering schools can truly claim that their programs have evolved in terms of core content and methods of instruction in order to maintain pace with modern professional engineering practice? Unquestionably, the effects of the Grinter report are still evident in much of the current engineering curricula.

In the late 1980s, engineering employers and educational leaders recognized that, for engineering graduates to be effective in the $21^{\text {st }}$ century, significant changes must be made to the engineering curricula, specifically with respect to engineering science content [7]. It was recognized that the Accreditation Board for Engineering Technology (ABET), the American accreditor of college and university programs in applied science, computing, engineering, and technology, had the ability to bring about or curb change. In 
the 1991-1992 President's Report from Prados [7], ABET recognized the need for change in its accreditation philosophy. It was noted that the focus on credit hours and detailed specifications must shift towards educational objectives. Until the 1990s, ABET was infamous for its protection of the status quo. Since the mid-1990s, however, ABET has been pro-active in evolving its accreditation standards. Evaluation criteria now focus on what graduates have learned and what they can do. In 2000, a new set of engineering criteria [8] were brought forth that limits the prescriptive criteria. A major focus has been placed on gaining representation from industry on the accreditation team. The resulting new "outcomes based" accreditation assessment criteria include more emphasis on design capability and professional skills. Although undoubtedly a step in the right direction, after decades of "accounting" accreditation criteria, engineering institutions continue to struggle with challenges, both in terms of re-structuring educational programs to meet the required outcomes, as well as in developing effective and consistent metrics as to how those outcomes are measured. A continued effort will be required to maintain the momentum in developing new and effective programming in order to ensure success.

The Canadian Engineering Accreditation Board (CEAB) has not yet adopted "outcomes-based: engineering program assessment, although changes are likely forthcoming. There are challenges in evolution, but in order to maintain pace with engineering practice, stakeholders in education must overcome the challenges and forge ahead.

\section{What Industry Wants: What Education Gives}

Following extensive consultation with industry, the Natural Sciences and Engineering Research Council of Canada (NSERC) concluded the following in their Chairs in Design Engineering Guide for Applicants [9]: “One of the major gaps in Canada's innovation system is the shortage of people with the skills and knowledge to make innovation happen. Specifically, we lack design engineers. Design engineers are the enablers of innovation and if we want to become more successful in innovation, we have to educate and train more of them." Industry and engineering have undergone significant evolution in the past few decades; it therefore seems appropriate that engineering education must do the same in order to maintain an effective pace.

As stated by Todd et al [10], "It is sometimes forgotten that industry is an important customer of engineering education. Ignoring this relationship has produced graduates that often fail to meet the changing needs of industry in today's competitive environment." Industry has a set of given needs that it requires of new engineering graduates to fulfill. As the result of an industry survey conducted in 1993 by Brigham Young University colleagues Todd, Sorenson, and Magleby [10], a number of significant weaknesses in engineering graduates were pinpointed by industry. Engineering graduates were found to: be technically arrogant; lack understanding of manufacturing processes; desire complicated and "high-tech" solutions; lack in design capability and creativity; lack in appreciation for considering alternatives; have a poor perception of the overall project engineering process; have a narrow view of engineering and related disciplines; have weak communication skills; and have little skill or experience working in teams.

In a later survey conducted by Frise et al [11], forty eight Canadian companies and twenty academic institutions were surveyed to compare what is most frequently taught in educational institutions with what is most desired by engineering firms. It was found that the most used skills in industry, as determined by industry, were, within the communication skill set - oral communication with clients, internal written workplace communication, and oral communication with colleagues. In the design skill set, the most used skills were determined to be creative thinking, design for cost, design for reliability, and design for performance. Within the people skills skill set, the key skills were found to be attitude, adaptability, leadership, and teamwork - part of what might be considered the "soft" skill set (although the authors of this paper prefer the term "professional" skills).

As Wissey [12] reported in 2000, the value of "soft skills," in addition to technical prowess, should be a priority for future engineers. To be successful, engineers must be team players. Engineers of today's generation can no longer be the "isolated innovator [12];" they must consider also what personal skills are involved in the position, from working with others to communicating ideas to environmental and social sensitivity. When surveyed, industry agreed that new engineers generally come to work with a solid technical education, a logical thought process, 
good work ethics, and computer literacy. However, Wissey also found that these engineers must develop a set of soft skills to add value to their performance.

In 2002, Eggert [13] performed a survey to determine the current state of "supply and demand" in engineering education. In this survey, 1006 industry representatives responded, as did 182 academic representatives. All participants in this survey were members of the American Society of Mechanical Engineers (ASME) and were employed or teach in engineering design or manufacturing. (Of the industry respondents, most were found to be instrumental in hiring. $73 \%$ of the academic respondents were from American institutions. $9 \%$ were Canadian.) Industry participants were asked what topics and activities they considered important. Academic participants were asked what specific engineering design topics were being taught, in which years, and what engineering design activities students participated in and when. It was found that there was a supply gap in academia's coverage of creativity methods, project management, design for manufacture, design for assembly, and product testing. Industry was also found to have a higher demand for individual design projects and interdisciplinary design projects than is currently being taught. A summary of industry's top 10 topic demands and top 5 activity demands, as reported by Eggert, can be found in Table 1 .

Table 1. Listing of industry demanded topics and activities [13]

\begin{tabular}{|l|}
\hline Top 10 Industry Demanded Topics \\
\hline Teamwork \\
\hline Engineering design specifications \\
\hline Design for manufacture \\
\hline Overall design process \\
\hline Design for assembly \\
\hline Creativity methods \\
\hline Project management \\
\hline Product testing \\
\hline Tolerancing \\
\hline Solid modeling \\
\hline Top 5 Industry Demanded Activities \\
\hline Team design projects \\
\hline Open-ended problem solving \\
\hline CAD-solid modeling \\
\hline Interdisciplinary design projects \\
\hline Design reports (written) \\
\hline
\end{tabular}

When the topics being taught by academia were compared with what industry demanded, it was found that there was a significant lack of teaching in regards to creativity methods, project management, design for manufacturing, design for assembly, and product testing. In addition, industry was shown to have a higher demand for individual design projects and interdisciplinary design projects than is currently being provided.

"To compete in today's global economy, companies need people with diverse skills, ideas, and knowledge [14]." Engineering students must be able to evolve with a rapidly changing industry. The Boeing Company has identified a list of desired attributes for engineering graduates. Compiled by Lahidji [15], the aerospace giant states that a successful graduating engineer must have:

- A good understanding of the engineering fundamentals

- A good grasp of the design and manufacturing process

- A basic understanding of the context in which engineering is practiced

- A multidisciplinary systems perspective

- Good communication skills

- High ethical standards

- An ability to think critically and creatively as well as independently and cooperatively

- An ability and the self-confidence to adapt to rapid/major change

- A lifelong desire and commitment to learning

- A profound understanding of the importance of teamwork.

Based on a literature review, Lahidji developed a survey to determine what competencies industry found important. Results were returned from 38 companies suggesting that applied engineering, communication skills, and interpersonal/team work were the most required skills for a graduating engineer in the field of manufacturing engineering.

Unfortunately, much of the data that has been gathered on the topic of engineering design education is either out of date, very much focused only on mechanical engineering education, limited by a small number of industry responses, or a combination of the above. From perusing the past decade of engineering education literature, it appears that very little research has been done in effectively determining what industry really needs from all engineering graduates with respect to 
design - and what engineering education is currently providing.

\section{Designing Design Education}

In 1991, Dixon [16] noted that "engineering design education...has for decades been, and continues to be, mired in dire straits and is intellectually stagnant, serving its students and industry clients only very poorly." Today, fifteen years later, both students and industry continue to question the quality of engineering education. As Dixon stresses that engineering educators need to determine what the fundamental needs of engineering in industry really are. Instead of teaching only the functional and technical aspects of design, it is paramount that the teaching of engineering design be as rigorous as that of engineering science. As today's science focused curriculum appears to be based on a decades old report, Dym [17] poses a few important questions: Has engineering curriculum 'stood the test of time'? Are engineering schools meeting society's expectations? Or are engineering schools simply resistant to change?

As Stefik [18] points out, "The engineering education system is an artifact, worthy of design." The point of "redesigning" engineering education, as Dym [17] comments, is not to create a brand new system, but to provide a structured approach to informed questioning. In redesigning engineering education, one must first determine a set of objectives. Objectives, in this situation, are dependent on the viewpoints of a number of stakeholders. Firstly, students want the best educational experience possible. Eventually, these undergraduate students will want to be able to find good jobs. In kind, employers want to be able to hire young, new graduates - who have the skills of experienced veterans and are prepared to do any job effectively and efficiently! Professors are often torn between teaching and the demands for research. Universities want their programs to be financially successful - and to be viewed as exciting opportunities for future students. Society is hoping for a graduate who will design the best possible engineering system - and who will protect society from harm. Each of these stakeholders has demanding expectations, and engineering education needs to find balance in responding to all.

In many current programs, design techniques, tools, and projects reside mainly in the "capstone" course for a given engineering discipline. Capstone courses arrive in the final year of the undergraduate degree. These design or research projects are the most frequently used mechanism to convey design tools, techniques, and hands-on experience - IF, that is, the tools and techniques of engineering design are even taught. It is important that, for a design project to actually qualify as being suitable for quality design education, it meet a basic set of guidelines. Often the products of design are emphasized, but the process used to develop the product is given little credit. As a result, design projects often involve "too much aimless wandering [19]." Information for a project or problem should be given as a problem statement or a client need for a potential new design. The project should not be based on analyzing an existing design or designing something that already exists unless there are clear objectives for improvement. Students should be required to make decisions to arrive at their unique solution and should evaluate their trial designs based on known engineering science, estimated cost, manufacturability, and design for X. During and following a design experience, students should receive constructive feedback on their design process performance, which in turn suggests that such feedback should come from those with engineering design expertise. It is imperative that, in the case of design projects or design problems, assessment of students must consider the design process used and not only the final result. Ultimately, engineering design should be the "cornerstone" of engineering curriculum rather than just the capstone [17].

In 1993, the Canadian Academy of Engineering issued a report on the state of engineering education in Canada, as a response to the evident lack of effectiveness. "Engineering faculties are perceived to be scientifically strong by the international standards but far from optimal in the contribution they could make to the initial and continuing education of engineers for effective practice of their profession in Canada [20]." The Academy recommended, amongst other things, that engineering education should have:

- $\quad$ Broader, less specialized, more integrated undergraduate programs with increased emphasis on design and social context

- An increased interaction between engineering professors and practitioners

- Enhanced professional experience for engineering professors.

In order to bring about these recommendations, significant changes within the current system of engineering education are required, with respect to cultures, policies, and practices in engineering 
faculties, industry, governments, and within the engineering profession itself [21].

As Dym [17] discusses, there are a number of considerable concerns with today's current engineering curriculum. The content being taught, in addition to the instruction of the content, is questionable. If industry is not satisfied with the current engineering graduates, there is evidently a gap between needs and availabilities. With respect to curriculum content, the Academy [20] suggests improvements. First, it was noted that most current Canadian undergraduate programs have a set time duration of four years. The optimal use of this limited time is to focus on a basic set of attributes, such as knowledge, concepts, techniques, skills, habits, and insights. As the lifetime of technical knowledge is short, focusing on these attributes will produce a well-rounded engineer who can succeed regardless of the age of technical background.

Dym questions [17], "Is engineering education broken?" Clearly, many positive outcomes have resulted from engineering breakthroughs in the past. However, there are also significant deficiencies in current engineering curricula, with learning, with graduates, and with the general operating style of engineering institutions. As such shortcomings are brought to the attention of key stakeholders, it is obvious that changes should take place. What is working right now as a bandaid solution to engineering education may eventually lead to a battered workforce [17]. Good engineering education is about the process; engineering students must learn how to think like an engineer. For engineering education to successfully evolve, it will require the effort of the entire engineering profession - from education through industry.

\section{Matching Educational Goals with Industrial Expectations: The Research}

In the fall of 2005, entry surveys were distributed in capstone courses at seven Canadian engineering and applied science institutions. Seventeen unique disciplines were examined and 827 students responded. At the end of each capstone course, exit surveys were distributed to the same students. The incoming and exit results were then compared to determine the change in knowledge, skills, and attitudes as a result of the final capstone design course.

The surveys distributed to students focused on a number of key elements required for engineering design competency as determined by a review of literature, industrial contacts, and a review of accreditation requirements. Firstly though, students were asked to state what type of course they were enrolled in by responding to a series of "yes, no, don't know questions." For example, students were asked: "Is your final year design course multidisciplinary? Is your final year design course team based?" The purpose of this preamble was to determine the basic structure of the capstone course. As the intention was not to compare school versus school, this enabled us to compare program styles instead. The second section of the survey targeted students' attitudes towards design. In this section, students responded on a five point scale from "strongly disagree" to "strongly agree." Questions were based on the desired outcomes of engineering education as listed in the ABET guidelines. For example, students were asked to respond to a similar line of questioning: "I like to tinker and redesign various devices/systems"; "I enjoy working in teams"; "Design is methodical"; "Engineering design is discipline specific". Students were also asked to rank their competency in a set of engineering design skills on a five point scale from "not confident" through "completely confident." In this area, knowledge and skills such as design methodology, idea selection, communication, risk assessment, and prototyping were evaluated based on the students' perceived competencies. To complete the evaluation of their current knowledge, students were asked to place themselves in a ranking of their design skills on a scale from 1 to 5 - "1" being "I know nothing" and " 5 " being "I'm a design genius." Finally, students were asked for their expectations of the final course - or, as in the final survey, what they learned, found most useful, and least useful from the final course.

In the winter of 2006, electronic surveys were distributed online to all accessible alumni of Queen's University Applied Science. Surveys were also distributed to industry representatives via NSERC Chairs in Design Engineering, and to industry contacts of Queen's alumni. In all, 294 industry representatives responded from a diverse background in industry and from a wide level of engineering responsibility, as can be seen in Table 2. 
Table 2. Breakdown of industry respondents by ranking in the OSPE levels of responsibility

\begin{tabular}{|l|c|}
\hline \multicolumn{1}{|c|}{ Level of Responsibility } & $\begin{array}{c}\text { \% of } \\
\text { Respondents }\end{array}$ \\
\hline & \\
\hline $\begin{array}{l}\text { Level A: Bachelor's degree in } \\
\text { Engineering or Applied Science } \\
\text { with little or not practical } \\
\text { experience }\end{array}$ & 9.1 \\
\hline $\begin{array}{l}\text { Level B: Level A entry } \\
\text { requirements with two to three } \\
\text { years working experience from } \\
\text { the graduation level }\end{array}$ & \\
\hline $\begin{array}{l}\text { Level C: Level A entry } \\
\text { requirements with three to five } \\
\text { years working experience from } \\
\text { the graduation level }\end{array}$ & \\
\hline $\begin{array}{l}\text { Level D: Level A entry } \\
\text { requirements with a minimum of } \\
\text { five to eight years of experience } \\
\text { in the field of specialization from } \\
\text { the graduation level }\end{array}$ & \\
\hline $\begin{array}{l}\text { Level E: Level A entry } \\
\text { requirements, normally with a } \\
\text { minimum of nine to twelve years } \\
\text { of engineering and/or } \\
\text { administrative experience from } \\
\text { the graduation level }\end{array}$ & \\
\hline $\begin{array}{l}\text { Level F: Level A entry } \\
\text { requirements with broad } \\
\text { engineering experience, including } \\
\text { responsible administrative duties }\end{array}$ & \\
\hline $\begin{array}{l}\text { Beyond Level F: Level A entry } \\
\text { requirements, with many years' } \\
\text { authoritative engineering and } \\
\text { administrative experience. }\end{array}$ \\
$\begin{array}{l}\text { Expected to possess a high degree } \\
\text { of originality, skill, and } \\
\text { proficiency in various broad } \\
\text { phases }\end{array}$ \\
\hline
\end{tabular}

The industry survey paralleled the capstone surveys in a number of areas. Firstly, industry respondents were asked to rank the top five most important design and development techniques from a given list. The list of techniques used for the industry survey was the same list of knowledge and skills used in the capstone survey. Later in the survey, industry representatives were required to use this list again to rate the current knowledge and skills of engineering graduates and to identify their expectations of engineering graduates in these areas. Industry respondents were also asked to rate the attitudes of engineering graduates from the list of statements used in the student surveys. Finally, industry respondents were asked what the greatest strengths and greatest weaknesses of Canadian undergraduate engineering programs were.

The surveys were then compared to determine where the key weaknesses in engineering education lie.

\section{Survey Results}

Although this is a work in progress, early results from the data suggest that there is a significant gap between what education provides and what industry desires. Interestingly, industry perceives engineering graduates to be quite weak in skills where students claim to be very strong. As a result, one must question how these topics are being taught - or introduced - to build this false confidence in engineering students.

Students were asked to judge their confidence in a range of engineering design skills on a five point scale from "not confident" through "completely confident." Over $40 \%$ of students responded that they were "very confident" or "completely confident" when it came to: conveying technical information, teamwork skills, written communication skills, and oral communication skills upon entry into their capstone course. Similarly, over $40 \%$ of students responded that they were "somewhat confident" or "not confident" with respect to risk assessment techniques, regulatory compliance, marketing techniques, safety and liability regulations, patents and intellectual property, safety techniques, reliability techniques, and market/application research.

Industry respondents to the survey had many interesting comments pertaining to the current state of Canadian engineering graduates' skills. When asked for feedback with respect to the greatest weaknesses of Canadian engineering education, a wide variety of candid responses were submitted. However, consistent with literature from the past few decades, there are a number of significant shortcomings identified by large percentages of industry representatives. Table 3 outlines the ten weaknesses that were identified most frequently by industry respondents. 
Table 3. Top ten weaknesses of current Canadian engineering curricula as identified by industry representatives

\begin{tabular}{|c|c|c|}
\hline & Weakness & Description \\
\hline 1 & Practical Skills & $\begin{array}{l}\text { Lacking in hands-on } \\
\text { experience; little to no } \\
\text { preparation for real-world } \\
\text { problems }\end{array}$ \\
\hline 2 & $\begin{array}{l}\text { Communication } \\
\text { Skills }\end{array}$ & $\begin{array}{l}\text { Lacking in oral and written } \\
\text { communication skills; } \\
\text { difficulties conveying ideas } \\
\text { orally and written }\end{array}$ \\
\hline 3 & Business Skills & $\begin{array}{l}\text { Lacking in background of } \\
\text { engineering economics, } \\
\text { budgeting, marketing }\end{array}$ \\
\hline 4 & $\begin{array}{l}\text { Ability to Work } \\
\text { with Others }\end{array}$ & $\begin{array}{l}\text { New graduates have no } \\
\text { multi or interdisciplinary } \\
\text { experience; have difficulties } \\
\text { working with other } \\
\text { employees (older, non- } \\
\text { technical, etc.) }\end{array}$ \\
\hline 5 & $\begin{array}{l}\text { Focus on } \\
\text { Theory }\end{array}$ & $\begin{array}{l}\text { Schools have focused too } \\
\text { many resources on } \\
\text { developing theory and } \\
\text { academics; narrow } \\
\text { education }\end{array}$ \\
\hline 6 & Design Process & $\begin{array}{l}\text { New graduates have no } \\
\text { experience with the design } \\
\text { process or design } \\
\text { methodology }\end{array}$ \\
\hline 6 & Teaching & $\begin{array}{l}\text { Professors present courses } \\
\text { poorly and have little or no } \\
\text { training; faculty appears to } \\
\text { be employed mainly for } \\
\text { research skills }\end{array}$ \\
\hline 8 & $\begin{array}{l}\text { Understanding } \\
\text { of Safety, } \\
\text { Regulatory, and } \\
\text { Liability }\end{array}$ & $\begin{array}{l}\text { Students have no concept of } \\
\text { the safety, regulatory, or } \\
\text { liability requirements one } \\
\text { must meet in order to } \\
\text { complete a design }\end{array}$ \\
\hline 8 & $\begin{array}{l}\text { Project } \\
\text { Management }\end{array}$ & $\begin{array}{l}\text { New graduates have little } \\
\text { experience planning a } \\
\text { project from start to finish; } \\
\text { few project management } \\
\text { tools are taught }\end{array}$ \\
\hline 10 & $\begin{array}{l}\text { Ability to } \\
\text { Think Critically }\end{array}$ & $\begin{array}{l}\text { New graduates lack the } \\
\text { ability to think critically; } \\
\text { unable to critically analyze } \\
\text { a design and its potential } \\
\text { risks }\end{array}$ \\
\hline
\end{tabular}

Ironically, three of the four skills that students perceive as their strongest points are identified by industry as the greatest weaknesses in engineering education.

\section{Conclusions}

To continue to adequately serve the stakeholders of engineering education, it is imperative that engineering programs evolve. Educators must take a look not only at what is being taught, but also at how it is being taught. It is clearly demonstrated by student's perception of having sound professional design skills, contrasted with the evident unfulfilled needs and wants of industry that there is a significant disconnect between stakeholders. A structured program to enhance learning in the identified areas of need must be implemented in order to achieve acceptable outcomes in engineering education.

\section{Acknowledgements}

The authors are grateful to those who offered class time to carry out the student surveys. We would particularly like to thank those who administered the survey in engineering schools across Canada on our behalf. Thanks also to both students and industry representatives for their participation in the surveys, as without their assistance this research would not be possible.

\section{References}

[1] Committee on Engineering Design Theory and Methodology et al. Improving engineering design: Designing for competitive advantage. Washington: National Academy Press, 1991.

[2] Brzustowski, T. (2004). Science and engineering research Canada: Design engineering and the innovation strategy. Presentation at the 2004 CDEN Conference, McGill University, Montreal. Retrieved November 5, 2004, from http://www.cden.ca/2004/CDENMontreal-2004-0729.ppt\#422,11, Slide 11

[3] Canadian Academy of Engineering. (1999, December). Evolution of engineering education in Canada. Ottawa, ON. Retrieved April 3, 2006, from http://www.acad-eng-gen.ca/publis/Evolution_a.pdf [4] Pool, R. (1997). Beyond engineering: How society shapes technology. Oxford, UK: Oxford University Press.

[5] Chiles, J.R. (2001). Inviting disaster: Lessons from the edge of technology. New York: HarperCollins Publishers, Inc.

[6] American Society for Engineering Education: Committee on Evaluation of Engineering Education. (1955, September). Summary of the report on evaluation 
of engineering education. Journal of Engineering Education, 25-60.

[7] Prados, J.W. (2004). Can ABET really make a difference? International Journal of Engineering Education, 20, 315-317.

[8] ABET, Inc. (2005, October 29). Criteria for accrediting engineering programs: Effective for evaluations during the 2006-2007 accreditation cycle. Retrieved June 13, 2006 from http://www.abet.org/Linked\%20DocumentsUPDATE/Criteria\%20and\%20PP/E001\%200607\%20EAC $\% 20$ Criteria $\% 205-25-06-06 . p d f$

[9] NSERC Chairs in Design Engineering. (2002, June) Guide for applicants.

[10] Todd, R.H., Sorenson, C.D., \& Magleby, S.P. (1993). Designing a senior capstone course to satisfy industrial customers. Journal of Engineering Education, 82(2), 92-100.

[11] Frise, P.R., Sirizzotti, M.D., Gaspar, R.G., \& Reader, G.T. (2002, May). Mechanical engineering skills needs in Canadian industry. Paper presented at the CSME Annual Conference, Queen's University, Kingston, Ontario.

[12] Wissey, T.W. (2000). Enhanced skills for engineers. Proceedings of the IEEE: Vol. 88, No. 8.

[13] Eggert, R.J. (2002). Engineering design education: Surveys of demand and supply. 2003 ASEE Annual

Conference and Exposition: June 2003 Staying in Tune with Engineering Education (pp.1901-1912).

[14] Davis, Isadore, Joe Tidwell, Ray Haynes, and Joe O'Brien. (2003, November) Corporate Connection:

What Industry Wants. ASEE Prism, 43.

[15] Lahidji, B. (2000, June). Competencies in Manufacturing Engineering Technology programs from employer's point of view. Proceedings of ASEE Annual Conference, St. Louis, MO.
[16] Dixon, J.R. (1991). New goals for engineering education. Mechanical Engineering: Engineering Design Science, 113 (3), 56-62.

[17] Dym, C.L. (2004). Design, systems, and engineering education. International Journal of Engineering Education, 20, 305-312.

[18] Stefik, M.J. \& Conway, L. (1982). The principle engineering of knowledge. AI Magazine, 3(3), pp. 4-16. [19] Jones, J.B. (1991). Design at the frontiers of engineering education. ASEE Frontiers in Education Conference: Session 22P1 (pp.107-111). Virginia Polytechnic Institute and State University.

[20] Canadian Academy of Engineering. (1993, September). Engineering Education in Canadian Universities. Retrieved April 3, 2006, from http://www.acad-eng gen.ca/publis/edu_an_2.html\#HEADING1 [21] Strong, D.S. \& Stiver, W. (2005, July 17-20). Engineering design competency: Perceived barriers to effective engineering design education. In R. Brennan \& I. Yellowley (Ed.) Proceedings of the $2^{\text {nd }} C D E N$ Design Conference. Design education. University of Calgary. 